DOI https://doi.org/10.36059/978-966-397-110-0/79-101

\title{
THE EXPERIENCE OF TIME (REPETITION) IN HISTORY
}

\section{Predeina M. Yu.}

\section{Based on cinematography and films With my expression of gratitude to Vs. Yu. Chekhanov, whose lectures about cinematography had inspired me to write this article}

In some periods of time history is made, in others - people get to experience it, experience what has been already made, and what has been already made begins to become a subject of thought and emotion. Such events cause time duplication to occur, a phenomenon of two time layers overlapping, as in the title of a well-known Karl Marx's work "The Eighteenth Brumaire of Louis Napoleon Bonaparte", so it is absolutely impossible to certainly make a statement which time is real: if we consider that the real is actionable and producing, could it be that the Eighteenth Brumaire is in fact not more real and producible then Louis Bonaparte? Isn't it or rather the shadow of Napoleon Bonaparte standing behind him creates six million voices of peasants for Louie's nephew? Karl Marx's well-known work is rather unhistorical in a sense that it looks into repetition, repetition of experience, experiencing history like workclasses of people passing from the picture: peasants want to re-create Napoleon Bonaparte for achieving a goal of defending themselves from repetition of making the same mistake, an unclear mistake that made them, free owners of parcels, quickly sink into debts, but from Marx's perspective it is not a mistake, something that is put them into debts, but rather a historical necessity. Marx makes a bet on the creation of history. I think I wouldn't be mistaken considering the influence that his work had on the 20th century, that Marx awoke our interest in comedy and tragedy of repetition, he made us up to date with Hegel's phrase "History repeats itself twice". Marx begins the "Eighteenth Brumarie" with a reference to Hegel, but he can not remember where Hegel said such phrase "somewhere" - writes Marx. I am not setting myself a goal of finding an unfound phrase, I'm going to mention that in the "Logic of the Science" 
trying to find the answer to the question "Where should we begin science?", Hegel says that in order to move forward you have to take a step back. Or if I directly quote Hegel: "Moving forward means going back to our origins, to your initial and true state, because that decides where we are going to start and that is what gives birth to a new beginning" . - Moving forward is in fact moving backwards. Abstracting ourselves from the logical arguments that Hegel proclaimed, I will ask you the following: where did he get his feeling? Even though everyone saw Hegel as an "emotionless" person his works are definitely not lacking emotion, his unusual for an uninitiated person language helps him express his personal emotional stress, one may even say for a confession. People who knew Hegel felt that, Heine for example (you could look up what Deirdre Lucacs in his work called "Young Hegel and the problems of the capitalist society").

Feeling of repetition is born within two times, in between-the-time, described within two structures: "not yet" and "no longer" - Hegel's time was exactly that time. If Marx had already found out that 1848 began a new era, an era of laboring revolutions, then Hegel lives in a time where what Marx said was "not yet...", but also the French revolution for Hegel is already "no longer...". When you live between-the-time you have nothing to do except experiencing the same thing that you have already done, but this experience turns into farce easily (Marx mentions that for the first time history plays out as a tragedy, for the second time as a farce which is definitely not pointless) - Just like farce with tragedy elements, tragifarce, there was a series of obtrusive efforts to repeat the French revolution in the years of restoration, that was attempted by a group of Italian revolutionists in a motion picture by Taviani brothers called "Onwards, sons of motherland! (Allonsanfan in French) "We came either too late or too early", - says Fulvio, a character in the movie to himself, but he actually says it with his dead companions mouth, who was killed by Fulvio himself, so he could escape fulfilling his duty. - In a film by Taviani brothers we could see the phrase that we are going to hear a lot of times in the future: "Too early - too late".

The life of Deleuze in a monumental work "Motion Picture" describes cinematography of Louis Bunuel as the cinematography of repetition. "In Bunuel's work we can see the replacement of entropy with

${ }^{1}$ Гегель Г. В. Ф. Наука логики. М.: Мысль, 1970, т. 1, с. 127.

2 «Вперёд, сыны отечества!» (Allonsanfan, реж. братья Тавиани, 1974), 74-я минута. 
the concept of a cycle or the infinite reversion" (but such infinite reversion that will break the vicious circle, free itself from the circle, and stop being eternal) "But isn't the repetition powerful enough to go beyond the boundaries of its cycles and "jump over" to the other side of good and evil? The repetition is destroying us, but it could also save us, and give us a chance to quit another repetition $\rangle^{3}$. - Louis Bunuel - is an unusual producer, who is known for his long life in cinematography: between his «Andalusian dog» and "Golden age», on the one hand, and for example «Humble charm of bourgeoisie», on the other hand, not only one epoch stands. However, it is even more interesting to ask a question: in which moment does repetition enter his works? «Golden Age», which was shot in 1930, has a feeling of the approaching threat, a threat of fascism, a threat that shows itself with a drum-roll, although there is no repetition, maybe history is moving in a wrong way, but at least it is going forward. Perhaps, it was the first time that repetition showed itself with such clearance ${ }^{4}$. Repetition shows itself in the «Angel of Destruction», which was shown in 1962 and we could also hear such words: the week-will. "We have to use all the strengths to overcome this week-will»", - says one of the guests, a doctor, the guests who have been invited to dinner and they are realizing that they can not exit the dining room. They do not have the will to do it. «Let's all stop talking for a couple of minutes, group up and we will use all of our will to try and exit» ${ }^{6},-$ says the ill-fated host of the dinner. But nothing else! - Our world that is chained with week will, the world that is resentful from its week will, the world that is ready to show the will only to make a sacrifice for its week will, - the guests who are ready to kill the host. However, all of a sudden one of the guests says: «How much places have we changed during this terrible eternity. We were thousands of different chess combinations, and now we are playing our own roles and recreating the same events of that evening.»> ${ }^{7}$. Let's go! Everyone, follow me! So they finally leave. However, Deleuze's optimism is too early: yes, they finally manage to leave, but only to get stuck again in a church after a thankful praying for their great rescue. - Bunuel also leaves no hope for the viewer in the "Humble charm of bourgeoisie", where two bourgeoisie families who constantly visit each other to have

${ }^{3}$ Делёз Ж. Кино. М.: Ад Маргинем, 2004, т. 1 «Кино 1: Образ-движение», с. 195.

${ }^{4}$ В «Виридиане», 1961-ый, мотив повтора всё же дан намёком.

5 Ангел истребления (по исп. El ángel exterminador, реж. Луис Бунюэль, 1962), 33-я минута.

${ }^{6}$ Ibidem - 36-я минута.

${ }^{7}$ Ibidem - 83-84-я минуты. 
dinner together never sit at the table to eat, this problem will never find its solution, even their death will not be their salvation, because it seems that they are immortal. It seems like the happiest ending to this story is a terrorist with a gun, who has broken into the dining room, but unfortunately he was just a dream of one of the sad guests. - Does anybody here have their will?

It seems like something that separates Bunuel's works into stages also separates cinematography as a whole into two stages, - cinematography of wars and revolutions is the cinematography of action, creating history, for example, in Eisenstein's work history is definitely "made", it is the cinematography of calmness, calmness that has already come, it is only realizable with time as its long-lasting, ongoing state, it is the cinematography of repetitive experience of the former history, it is the reflection of the former history. It is possible that if we ignore some indecision we could clearly see that repetition is represented by a way out, especially if no one could find another way to find a way out. -We could see the same repetition being used in Taviani brother's film «Onwards, sons of motherland!»: Fulvio-senior had lost faith in everything, he does not have any energy left to believe in his beliefs, but on the other hand, his nephew, who has the same name as his older brother (a clear example of repetition being used in the film), Fulvio-junior experiences the world with a thoughtful look that more reminds us of a judge then of a child: what has caught his eye? What judgment did he make? What kind of path did he form for us? We expect the repetition from that boy, and maybe with that repetition he will find a way out. - It is interesting to know that Taviani brothers in their film which was shot in 1974 re-created the years of the Restoration and they did it in a very modern way, the film does not look like a «historical picture» at all. - Now we could feel exactly what Hegel felt, but what Hegel felt after Marx's dream could only be described as finding repetition for the sake of discovering a way of achieving that dream.

And finally, to finish our long-lasting introduction: why did I choose cinematography? - It is because cinematography is no longer considered as only a form of entertainment, it has become something «intellectual» (I'm quoting Deleuze here) and with that he saved his emotions, feelings in his «intellectual» variants. And we could feel that strong emotion during two or more hours, so if I would refer to one of famous creators, it «emotionally touches» for a couple of days, especially if we are talking 
about books, writers had a lot of time to express exactly what they wanted, but if we are talking about films it is an entirely different thing because a film has to do the same in only a couple of hours, in that aspect cinematography shows a lot of efficiency. - Just as the same author said, the author of the words about «emotional touching»: "Circus and cinematography are the most important forms of art for us».

\section{I. - Too early, too late}

«Too early - too late» - is a film by Jean-Marie Straub and Daniel Yue shot in 1981, it places the viewer between two times at once: we can hear Danielle Yue voice reading letters from Engels to Kautsky, which were written in 1889 mentioning the Great French Revolution; we can see the French provinces where Engels gave Kautsky statistics in 1789, they see them just as we can see them now, that means that they see them at present time, in 1981; we ourselves do not really know in which time we are because there is no contradiction between our ears and our eyes, our ears hear about poverty, and our eyes see it, but only when our ears hear the unusual «in seneschal», our pedantic brain stars to reminds us «this is not about our present time». - To be exact, this film has even more than two times, and only our limitation makes us think that there are only two of them, - times even overlap each other in Engels's letter, and in that letter there are also more than two times. The easiest problem to solve is the one with the formal reasoning of the letter: Engels reacts to Karl Kautsky's article, which was published in «Neue Zeit», probably to the anniversary of the French Revolution, Engels criticizes Karl Kautsky because his article has every common flaw that anniversary articles usually have, articles that are usually written dedicated to some occasion, which means they are written superficial and without any actual detail. However, the statistic, which concludes a big part of Straub's and Yue's film is borrowed by Engels from «the best work about peasants», which was written by Nikolai Kireev in Russian in 1879, and a question arises: why all of the sudden and what for Kireev started working on the «issue about peasants» just right at the French revolution eve? To put a question means to answer it: therefore, the French «issue about peasants» was actualized for Russian. - First of all, Marx and Engels got interested in Kareev's work because of the land rent, and secondly, they were learning 
about the Russian revolutionists' movement, - it turns out that not only times overlap, but revolutions as well.

First five minutes of the film it turns us around the Bastillian square, it spins us to giddiness, - I'm not sure that it is exactly the Bastillian square because I'm kind of a stay-at-home person, but if we think about it logically we definitely should be there. If I'm mistaken - then it is only worse for the facts. All of that time that we are turning and spinning around until our vision gets blurry, the voice of Danielle Yue manages to keep up with the speed of frames rapidly changing, he slowly reads: «It turns out that bourgeois have shown their cowardliness once again, just as they always do, they are too weak to defend their beliefs; starting with Bastille plebs had to do all their work for them; without their interference on the fourteenth of July, from fifth-sixth of October to the tenth of August, the second of September, etc. ancien régime would definitely defeat bourgouise, the coalition made a union with The Royal Court and would supress the revolution it would the only way for plebs to accomplish their revolution» ${ }^{8}$. «Just as always». We should feel giddiness from spinning around a circle, but not only from our successes, but also «just as always», but that «just as always» could only be understood in a context of 1830 and 1848 years, where the July Revolution and the February revolution took place. - Just in case: French people had their own February revolution. - We see a black screen soon after that, which is followed by Yue reading Kareev's statistics.

«Just as always» also has a different name «too early-too late»: the movement begins "too early», when we do not have an understanding what our goal is, and understanding comes to us «too late», when there is no movement and our goals are replaced with exhaustion. - On the twenty fourth minute of the film the camera turns to a scene somewhere in a French province, where at the edge of the village, somewhere near the roadway, with a slogan that says «The peasants will rise again!» While our eyes can see the wall, our ears hear the following phrase: «The formula of «welfare for all is based on labor» - this quote was too precise to describe the motivation of plebs brotherhood at that time period. No one knew what they wanted for a long time after the commune had fallen, and Babeuf did not want to put it into a certain form. If the commune with its ambition to join the brotherhood spoke out too early, while Babeuf, in 
his turn, came too late» ${ }^{9} .-$ But if the Commune spoke out too early, that means that it was the reality, and reality always comes too early, when Babeuf was only a speculation, a speculation that was striving to be fulfilled in farce «The conspiracy of the equals», even if he saved himself from the farce, he paid the price of his partners lives, who were executed by the government. Should we mention that Babeuf is a tragic figure of the French revolution, tragic because he had to realize that «I came too late»? Isn't this what he realized when he, got released from prison in 1795 , forms a conclusion that «in order to reeducate our people who are in devotion to freedom we need more than just to conquer it»? - These words that I have remembered were said by Babeuf and they definitely set the tone to the phrase that we have just heard, but what shadow does Babeuf's figure throw back on such slogan?

We have time to think about that: Yue will finish reading his words and camera will hold this slogan in our sight for three more minutes, the viewer is going to look at it and hear the noises of cars speeding by. Does it bother the invisible, but noisy cars that are passing by in complete indifference right past the slogan, giving him a judgment of «too late»? - Repetitions include each other like a matryoshka, doesn't it promise that another repetition will break the circle of repetitions to end the «infinite reversion»? However, who will break the circle of repetition? While discussing repetitions we almost forgot that repetitions aren't made by someone, they are made just like a desired repetition, that will end all repetition isn't a gift from the heavens, someone need to create it. Who? - The film by Straub and Yue discovers the absence of someone, or we were to say it in a philosophical language, it discovers the absence of subject, literally the absence of such word - in the film, precisely in its first French part (there is a second Egyptian part), there is no people, no one. - We hear cars passing by, but we do not see people, it is like people do not exist on such abandoned land, trying to skip it as fast as they could. For this deserted, abandoned land it is «too late», there are no people left on it.

\section{II. - Comedians}

«Comedians», a film by Theo Angelopoulos, shot in 1975, is a fiction film, and the producer finds another methods to show the viewer how two

9 Энгельс Ф. Карлу Каутскому, 20 февраля 1889 г. // Сочинения, 2-е изд. М.: Политиздат, 1965, т. 37, c. 127. 
time layers overlap each other - he does not split two time layers between two main receptors in the human body that are used while viewing the film, them being hearing and eyesight, but he rather fills one street with two times, that's why you will need time to adapt to the film. Let's assume that we appeared on the street where we felt two different states, happiness and sadness, enthusiasm and despair, at that exact moment we are walking past that house, we are walking in current time, but right as we get to the next corner we discover that current time for us has changed, we are seeing and hearing, we are experiencing what had already happened here, that is exactly happens in Angelopoulose's film, we join the main heroes as they walk into the street in 1952, we could hear elections slogan's of some general being shouted through the loudspeaker and suddenly we are travelling ten years back in time and through the same loudspeaker we could hear an announcement that doctor Gebbels has arrived. This is unexpected for us, but not for the heroes, this is the time that we need to adapt to the movie, - this is the time that we need to acquire a luggage of memories, that in the first frame of the film heroes already have, but we don't. Angelopoulose's film is structured vice versa, in a lineal storytelling first frame should be the last, and the last should be the first. «In Autumn of 1952 we went back to Aegion, we stayed as the same troupe, also we are very exhausted and we have not slept for two days $\rangle^{10},-$ The off-screen voice says after the curtain is lifted up for the first time, just as we get to see the troupe, that is slowly concentrating on a square that is located near the railway station (We could have easily mistaken Aegion's square that is near the railway station for the regional centre square that is also located near the railway station.) "We still remain as the same troupe a little bit». However, how less is a little bit? The first frame of the film immediately ruins the intrigue, we see who managed to survive, but what we are seeing at that exact moment gives us nothing as we do not know their names and who these people are. Strictly saying, if we were to answer the question of "How less?» we could only answer that after the last frame, where the offscreen voice will read these words: "In Autumn of 1939 we went back to Aegion, we stayed as the same troupe, also we are very exhausted and we have not slept for two days» ${ }^{11}$. It is the same square near the railway station, and the only thing that changed is the troupe, and only in the last frame we realize what price has the troupe paid for these years. - This

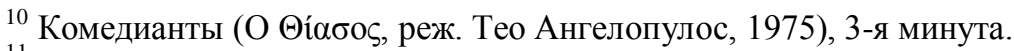

${ }^{11}$ Ibidem - 221-я минута.
} 
amount of time that we get to experience in the film is the amount of time that we need to fully get attached to the troupe and understand the last frame to the point where we could switch places with the characters - in the first frame the characters of the film already had what we did not - a luggage of memories, but in the last frame the characters are free of that luggage of memories, but we are heavily affected by them, we feel tears on our eyes when the characters do not have a reason to cry yet.

In Angeloupouse's film two plays are being played out, they repeat each other, - we could see the cinematography of repetition here as well, just like it is in Bunuel's works. - When you hear the word comedians you probably think about two loud actors, glitters and tinsels, that is just as wrong as imagining Greece as a warm and luxurious southern county, in a lot of the frames we could see piercing wind and sometimes even snow falling down, glitter and tinsel do not separate us from the comedians, there are no glitters and tinsels, and even if they are comedians they are comedians, they are only comedians in a sense that we are all comedians, one way or another living our life. They are comedians in a sense that August Octavian has inlayed in his words: "If we played good, then applaud us and tell us good advice on our way back». - The first play - is the play that they are performing, it is a play about an unwanted love of a shepherd girl named Golfa; there is no need to say, that the play is the same each time, but the hall and what happens around the hall, sometimes it is the howl of bombers, sometimes its Germans, or something else. The second play - is the play where they live, we do not realize it at first but the life of characters in the film is also a repetition of some old play that was performed a long time ago, only the names of the brother Orestes and his sister Electra give us a hint. -We are not present at the pastoral of Golfa, we are present on the «Orestes» of Aeschylus. In the decisive moment we realize, that "Orestes», or to be exact its second part, "Sacrifice on the Tombstone», where two plays intertwine: Orestes appears on the stage where the play about Golfa is being performed just to shoot her mother and her lover two times, to shoot the traitors, that have denounced to the Germans that he had left to join the guerilla, and in revenge they have shot his father. Should we mention what Electra told Orestes about family relationships? - It is an old story, which intellectuals have used to analyze fatherhoods law victory against motherhoods, it actualizes and repeats itself to a new form, and there is a 
very small chance that someone will see the problem between fatherhoods and motherhoods law in it, in it we could hear something that Aeschylus did not have - a small human being, a father that does not look like Atrid, who is proud of his fame, who is the ruler of husbands of Agamemnon, he is thin and puny, but nonetheless he is more of an Ellada's son then Atrid is, he is more connected to his home land and maybe even to that neverending play that is being performed on that earth. - «I am from Ionia, where are you from?» ${ }^{12}$ - Father asks the Germans, as he is being shot. For some reason he does not find this as important as it is. - There is Agamemnon, there is a Sacrifice on the Tombstone, but there is no Eumenids, there is no Athena, there is no upper instance which if not sets the justice, then it sets the law, it sets something what is the law and of course what is not considered the law, let me remind you that if Orestes was taking his revenge on Klitenmenstra for taking Agamemnon's usurped priorities, Klitenmenstra was taking her revenge on Agamemnon for taking downtrodden law from Iphigenia, one law against another, Athena decided which of the injustices (justices) was the law, and which is not, even if she does not reconcile both sides, she will set peace upon them, norm that we should obey, even if we have to close our hearts.

Aeshcylus's Orestes needed Athena, but Angeloupouse's Orestes did not, but that's why there is absolutely no chance for peace here, there may be strife and victory, but definitely not peace. Aeshcylus's Orest promises Athena to obey her and ends this story, it is not important what the verdict will be, this verdict will end strife and disagreement and will law and norm upon everyone, and the choir's prophecy which was told at the beginning will come true:

«Through suffering and pain

Zeus will lead mankind to intelligence

To intelligence he leads.

Persistently remembering our suffering

At night, while sleeping, it hurts our hearts

Against ours sharp mind's will.

Heavens don't know the meaning of mercy

Strength is Gods greatest mercy» 13 .

However, our Orestes does not need to be educated about intelligence, he rejects the God's law just as he would reject the law of

\footnotetext{
${ }_{13}^{12}$ Ibidem - 75-я минута.

13 Эсхил. Агамемнон // Трагедии. М.: Искусство, 1978, с. 188.
} 
some higher instance, such as English and American people when they replaced the Germans, educating him is a motive that is perfectly represented by Jean-Marie Straub and Daniel Yue in their film «From darkness to rebellion», - the events of the film take place on the same earth, the earth of Ellada and Italy, from time to time, from generation to generation, rebellion breaks out more and one question arises: Why did we as people let Gods to appropriate these rights?

Too early - too late. How could you live without it? If the concept of «too early - too late» did not exist, then maybe this kind of cinematography wouldn't exist, it is the cinematography that emerges us into emotional stress, into experiencing the repetition of time. «The air of freedom is in the air. Onwards! And let's all cry from the bottom of our lungs: Onwards! Onwards! Let the slaves rise once again, let them come to life! ${ }^{14}$ - the crowd sings on the square after liberation, and in the sky over the crowd flags are waving, all of them, soviet, American, Greece. This is also repetition, but it's more likely that it's the French repetition of 1789, 1830 and 1848. We could read what Engels is writing and Yue is reading: «But that (here he talks about the French Revolution's success because of the plebs - M.P.) would be impossible if the plebs would not contribute to the bourgeoisie's demands such meaning, that was not there, if they would not make final decisions about equality or about the brotherhood, and if they wouldn't turn bourgeoisie's slogans upside down because these slogans turned into their exact opposition. The brotherhood and equality of plebs could only be a dream back then, when people were discussing about creating something completely opposite to them and just as always, just as irony in history goes, the plebeian understanding of revolutionist's slogans became the most powerful impulse to achieve the opposition: bourgeoisie's equality in front law and the brotherhood - in exploitation» ${ }^{15}$. - If we were discussing about Greece's opposition, it was lead by the plebeian understanding of equality and brotherhood, but it was not the plebs who have appropriated the benefits of their victory, just as victory was prevailed it was possessed by the titleholder - bourgeois and its allies, to be exact: Marshall Papagos, whose aristocratic opposition against Germans, his royalist contumacy were converted into the leading post. Plebs went from victors to criminals. «Long live Marshall Papagos!

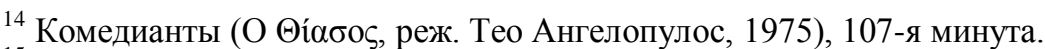

15 Энгельс Ф. Карлу Каутскому, 20 февраля 1889 г. // Сочинения, 2-е изд. М.: Политиздат, 1965, т. 37 , c. $126-127$.
} 
If we do not want to see violent gangs with sickles and hammers roaming our streets, if we don't want a new Red October, then we should all unite and support the marshal... Long live the national forces!», - this is what we hear on the fourth minute of the film, this is what the characters of the movie hear through the loudspeaker when they are in Egion. On the six minute of the movie when they come to a another corner, they hear the same speech while being in a different cast: «Tomorrow the minister of the Third Reich's propaganda doctor Gebbel's will come to our city, the national youth organization invites you to meet him, we require you to be dressed in a flawless suit». - Just as always, just as irony in history always plays out, the plebs contributed amazing efforts to gain absolutely nothing, and that's what Angelopoulos manages to greatly represent with the help of a loudspeaker and constant noise changing. - The protest where under every flag people sang about the wind of freedom quickly changed to strife and street fights: «We are going to destroy palaces and thrones, heavy chains of captivity, emblems and law, living like this should be drowned in blood!»» ${ }^{16}$. An interesting Greece song that we could hear as repetition: "We are denying the old world, we will shake off its ashes from our feet...».

And even thought we are too late as always, in Angelopoulose's film there is someone who is going to repeat history and maybe he will break the cycle of repetitions, if we were to say this in philosophical language, subject, or if we simplify it: a human. - Orestes and Electra never give up even though they carry a heavy burden on their shoulders, he will be someone who could start everything over, he would revert time to something that once motivated Orestes and Electra to move forward. $-\mathrm{A}$ child - A child that must make an important choice is very common in mythological history; Angelopoulos leads us to that child in the film just like he leads us to everything in the film - gradually. - Neither Orestes nor Elektra have children, but their sister has a child. Elektra's sister, just like Antigona's sister evades family matters, a matter of dignity, she gets married with an American officer. We can ignore the fact that this American officer or even a noncommissioned officer is a paradigmal figure for cinematography that leads us to the years of occupation either of Greece or Germany. (I am mentioning the occupation of Greece with consideration of past events of the Red October, when allies stood de-

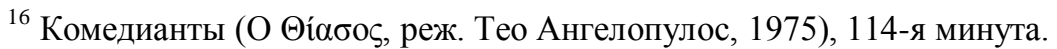


facto to one side of the barricade with people from which they were liberating Greece with pro-fascist forces)

An American officer that gets control of our woman, either Greece or German, and by taking our woman they are emasculating our man. One of the most important decisions of that theme belongs to Reiner Werner Fassbinder in the film «The Marriage of Maria Brown»: When Maria's husband came back home from captivity, he peeks into their slightly opened bedroom door just to see a black noncommissioned officer trying to engage in a contact with his wife, and when the door opens wide, either by him or the draft that's howling around, the first thing that her husband does is he rushes to the bedside table, grabs an American cigar and smokes it greedily. - Angelopoulose's American officer is just like all of them are - very naive, and he doesn't realize in what metaphysical tragedy has he got himself into, even the Germans are more likely to answer the father's quote then he is: «I am from Ionia, where are you from?». His American officer is a representation of money and landlessness, but not in a form of landlessness peasants, it's a representation of the quote «Money doesn't have an owner» opposing the quote «There is no land without an owner». I'm going to mention that everything that concerns owner's attachment to the land is the same attachment that peasants have, the land in fact owns them, just like Proust have noticed, you could find materials either in German duchess or in François, who is his Proust's servant. - Husband of Maria Brow rushed to smoke an American cigar, but Electra's and Orestes's son didn't even touch anything at the wedding table, he didn't even reached his hand to his mother's American husband, that kindly said: «Hey, little guy!». His son chose Electra. - The marriage scene is the most heartwarming and lighthearted scene of the movie, it's the first time we see the warm sea, sun shining and for the first time we hear lighthearted music playing, but for all of that they had to pay the price of rejecting their battle, the price of selling themselves to those who have killed Orestes. The earth and the sun do not belong to Ellada just yet, they need to be conquered and fought for just like his grandfather, Orestes and Elektra did. This is the path that their son chooses.

\section{III. - Last Summer in Marienbad}

Alain Resnais is mainly a producer of films that are based on politics, but we could see the repetition in his non-political film «Last Summer in 
Marienbad», which was shot in 1961. - Alain Resnais was making films about Genrike and Hiroshima, two cities that were affected by the experimental bombardments. «Try to calm an animal that feels that death is coming. Go ahead and try to explain to the mother why her son has died. Try gain peoples trust you when everything is on fire», ${ }^{17}$ - Reads the off-screen voice while in the films we could see frames of Pablo Picasso's «Genrika», that tries to run away, that tries to set herself free from people's hands, neighboring with who became dangerous, innocent, uninvolved horse, a mother with a dead child, a man who got to be responsible for children and woman by traditions and who is unable to protect them, a man whose hands are tied to the ceiling of the basement, where a lamp swings on the ceiling. Death makes humans and animals equal. In Genrike and in Hiroshima people have run into something that they can't even fight against it, it's something that easily wins over them, even if there are survivors in Hiroshima, they are only temporarily alive. We see frames of doctors helping those who have been burnt by the nuclear fire, doctors who making hard operations on those who are alive but have been already destined to die. These doctors do these things even if they are pointless, they are doing to save our human society, to support human relationships, even if they don't really matter after what happened. People try to seek help and help each other as it still matters if they help each other or not. Soldiers carry injured people on stretchers, doctors operate the, - people still have interest in each other and they are socializing, they still have relationships between each other even thought the civilization just collapsed right in front of them. «Try to gain their trust, when everything is on fire» - reads the off-screen voice and we see a helpless man, who is just like the horse rushes into the despair. "Try it...» - is a verdict, this is the death of the subject that we were talking about, that we were creating all this time, who we were educating with politic brochures, manifests and protests. If the destruction of Gernike was an experiment about the effectiveness of using fire-based demolition bombs against citizens, that experiment had one more interesting aftermath that could be summarized as this question: «What is our politic line worth against a bomb?». "Try it...» is addressed to the Spanish republican, not the German pilot. - It seems that in "Gernike», which was shot in 1950, Alain Resnais doesn't know the answer just yet, more specifically, his

\footnotetext{
${ }^{17}$ Герника (Guernica, реж. Ален Рене, 1950), 8-я минута.
} 
answer doesn't go over the lines of his moral imperative: «Under Gernike's dead oaks, in Gernike's ruins, under the clear skies of Gernike a man returns holding a bleating goat and a dove on his heart. He sings the song of uprising for the people, he is thankful for love and he denies anger $\gg,{ }^{18}$ - Reads the off-screen voice as we see another Pablo Picassos work, it is the repetition of Greece's «Moshofor», a man who is carrying calf, who is in peasant's vision is an antic anticipation of Christ. -Yes, it's an uprising. And yes, it is the purity. «Purity will defeat all crimes», concludes the voices. Gernika will win because it was pure. But Hiroshima wasn't pure. - That is exactly why «My love, Hiroshima» which was shot in 1959, is Alain Resnais's new understanding of this problem in my opinion. Purity is not a condition; it happens that Genrike was on the right side, and Hiroshima was on the wrong side. When the camera shows us the protest, and the off-screen voice reads: «The anger of the whole city is targeted against discrimination from one nation to another, does not matter if we are admitting it or not. It is against racism from one race to another. It is against discrimination from one class to another.», ${ }^{19}$ - Could we ask what was «Japan doing in Asia?» - ? - The answer is of course going to be no. When we see soldiers carrying injured people on stretches, could we ask «Have they been to China and Korea?» - ? Of course we couldn't. No, because a new subject has been already born, a new subjectivity, if we mean a kind of disseminated ability to be a subject, its dissemination between people, people who are still going to engage in human relationships in a time where human interactions and relationships lost their sense, and those who continued to engage in those relationships showed other people that relationships aren't pointless. That bomb destroyed all relationships, the rushing horse freed itself and ran away, but people stayed and fulfilled her duty.

«Last Summer in Marienbad» - is a non-political motion picture, it is a film of illusions, it is the same illusion as Hiroshima, Hiroshima that was seen by the main heroine of the movie, a French girl, an actress «just like when you are in love, an illusion appears, an illusion that you will never forget, and that's exactly what happened to me, that's how I see Hiroshima, just like I see love», ${ }^{20}$ just like in my vision of Hiroshima:

\footnotetext{
${ }^{18}$ Герника (Guernica, реж. Ален Рене, 1950), 11-12-я минуты. 11-я минута.

${ }^{19}$ Хиросима, любовь моя (Hiroshima mon amour, реж. Ален Рене, 1959),

20 Ibidem - 9-я минута.
} 
Could we ever deny the fact that these doctors, these soldiers, all of this people did not know about what going to happen, they did not know that they are only temporarily alive, maybe their biggest fear was not the bombs or the diseases caused by radiation, maybe they were in fear of being scolded by the government?» - In «Marienbad» We do not know and we will never know what was an illusion, what happened last summer, we will never know if that man actually loved this woman last summer, have they planned a meeting this summer or not, he says «yes», but she, he remembers everything to the smallest details, but she does not remember anything (Or maybe she is too afraid to remember?). Just like in love an illusion appears, an illusion also appears in history, and that's an illusion that we will never forget. The fact that he remembers everything could mean that nothing happened. - Events take place in a hotel which has been and old castle before, more like a baroque mansion, a hotel that is not located at a point in time, it's an oasis of an old world, where time doesn't exist: She is not the only one who can not remember what happened, but there is also two gentleman who can not remember if light frosts were on last summer or on the summer that was before the last, either in twenty eighths or twenty ninth, they always talk about the same thing and they forget about it every time. It is so strange that the twenty ninth and that castle, that castle and the historical time, a giant crisis or the Great Depression. - Time disappeared for that castle just like that castle disappeared in time. "In a speechless castle, where sounds of footsteps are absorbed by giant, heavy rugs, that are so thick and heavy that any sound of footsteps is immediately absorbed, just like if our ears could walk through this hallway, these galleries, these buildings of some different period in time...» ${ }^{21}$. In this buildings of some different period in time, in these living rooms of some different period of time, these labyrinth of French geometric gardens, there you absolutely can't get lost, but it's very easy to lose your way, the past disappears just like it disappears in labyrinths of libraries, in endless tomes of interpretations. Just like those two gentleman don't know when these light-frosts were, they hope to find this information in a newspaper, but I can't believe that they will find out how she begins to forget him, if she even knew him last summer, because we will never find out about the past, we will never find out what happened in the twenty ninth, and that means we won't know what

${ }^{21}$ Прошлым летом в Мариенбаде (L'Annee derniere a Marienbad, реж. Ален Рене, 1961), 2-я минута. 
happened before that. - Did she even love him last summer? It's not important; What is important is if she is going to go away with this in mind: if she is going to go away with him this summer, that means that his words «we loved each other and promised to meet again next year and never get separated again». And these words would be the truth, even if they were just an illusion, by deception of his memory, if she does not go out with him that means that these words will be a lie, even if they were already said. Illusion becomes the truth in motion, illusion becomes reality as much as it creates reality. "Wasn't the great Moloch ruling here?» - asked young doctor Marks, who has critiquing typical representation of reality. If the illusion is bad it is definitely not because it's an illusion, but because it confuses us in endless corridors, it forces us to make the same mistaken again, just like French peasants did with Louis Bonaparte, and even then the illusion doesn't become worse, it is just not an illusion anymore if it helps us to free ourselves from the endless corridors, if it rewinds time for us and gives us a chance to have effect on it. - She leaves the castle along with him, when they finally find an answer to the question of repetition.

What Deleuze says about Bunuel's cinematography, or to be precise Resnais' cinematography, and Resnais definitely relies on repetition's productivity, and repetition in Resnais's work is a tool that turns illusion into reality. - In between-the-time we would be too self-confident, if we thought that our theories, our political lines are at least somewhat true to reality, and we can not rely on the past, because the past either lost our the faithfulness of what was real, something that we have already done, or to be exact, what we are still doing, or maybe it never had that faithfulness in the first place, while it was always existing for us, who were born too late, like a destiny, like a legend, a heroic legend. «No one would approve my opinion about Spain. I don't even like it myself» - says Diego, we will call him Diego because he has too many names, he is a Spanish communist, he is middle-aged and a hero of a movie called «The War is over» which was shot by Alain Resnais in 1966. "Oh, longsuffering Spain! Heroic Spain! I am so fed up with all of this; Spain became a conscience for everyone, a myth for retired warriors. Nowadays there are 14 million tourists visiting it. Spain is heaven for people who are spending their holiday there and it is a legend about civil war. And I'm also very fed with the theatre of Lorca, I'm tired of its village dramas! And stop it 
with the legends! I have never been to Teruel, I didn't not participate in the battle near the Ebro» ${ }^{22}$. - «The war is over» - Resnais talks about Spain one more time, and at first sight this movie is completely opposite to «Genrike» - as a legend about Spain, and «Marienbad» as a legend as a whole, Diego want to free himself from the world of the illusions, he want to get to the real Spain, not a dream of thirty sixth, but to the reality of sixty fifth, but if we look closely we could see that all of the relationships in the movie are based on legends, dreams, illusions, and that means that legends could be productive. In some type of way Diego frees himself from the hands of illusions, he ruins his relationships with others, with his friends, but without these relationships it is impossible to really do something for Spain. - If fourteen million tourists bothers us, that means that the dream of thirty sixth, on the contrary is it that bad that fourteen million people couldn't ask themselves «Is the government there democratic?» Before going there to spend their holidays near the see? «In Spain there is a revolution that has been going a quarter of a century revolution going, but tourism is still the best source of income for the government, nowadays millions of people think that Spain is a normal country and they only associate with sweet memories that they got while spending their holiday there, this is a dangerous factor for politic mystification, and the activity of the European anti-fascist is slowly fading away. This is why we should have an impact on tourism!» ${ }^{23}$ - says the young revolutionist, a terrorist, but unlike Diego who is Spanish, he is French. What brought them together? Nadine is a daughter of an engineer who gave Diego his passport so he could travel to Spain, but most importantly - «quarter of a century revolution situation» or just an illusion about that situation, strictly saying, we don't know if that situation exists there and even people who live there don't know if it actually exists, and we won't know if it's real unless we will start acting like that situation actually exist.

That means that the situation that we are currently in is the same situation that happened in «Marienbad», we do not know if we loved each other last summer, it is uncertain if we were waiting to meet each other during the year, we also don't know if the Spain revolution even happened, we do not know if its going to wait quarter of a century for us, my memory could have easily tricked us, I could've liked her and thought

\footnotetext{
${ }_{22}^{2}$ Война окончена (La guerre est finie, реж. Ален Рене, 1966), 44-я минута.

${ }^{23}$ Ibidem - 103-я минута.
} 
that we loved each other, my political line could've tricked me... but she went out with me! - Diego travels to Spain one more time (using someone else's passport) so he could do something which he was trying to prove that wasn't actually possible for the last couple of days, which we, the viewers were witnessing for the last couple of days. Does he believe in repetition? It is unimportant, we do not know what is going to happen in the future, but he believes in human relationships, brotherhoods, that was born by who? Maybe vision of what is real changes: reality isn't a true fact, and human relationships, revolutionists Spain exist because people exist, that act like it actually exists, people, whose brotherhood is based on it, and it is very important to acknowledge that this is what produces, creates it in our reality. This something could be an illusion, but that illusion could be productive because it produces human relationships, and we need to evaluate this illusion based on its production of relationships, if we look at this from the point if the relationships that were produced could free themselves from the bewitched circle, their love in Marienbad could be a mistake that was created by his memory, but it helped them to find a way to quit the castle, and the light-frosts on the twenty ninth could also be a mistake or maybe it isn't a mistake, but they are unproductive either way, because they don't lead us anywhere, they leave both gentlemen in an enchanted castle, and the revolutionist Spain could also be just a legend, but it creates relationships that let us to take action on some events, and the movie has a clear ending scene - the beginning of a new action.

\section{IV - Yearning; Instead of Imprisoning}

We saw how relationships are being made; maybe they are made based on illusion, relationships in which children are involved, in a literal and metaphorical sense, because those who was taking action, children, like Ramon, another character of the film "The War is over», that has never been to Spain, he is a son of those who fought there, nowadays he is already an adult even thought he is clumsy and he is still a big dreamer in heart, because his dream about Spain is his method of escaping his everyday routine, because his dream about Spain helps him communicate and make new friends, when Ramon's hearts stop beating, we are going to see his friends that have came to say goodbye to him, these people aren't tied by blood, they are tied by something much stronger then blood. - But 
what if his heritage is not even an illusion? A film by Rainer Werner Fassbinder «Katzelmacher», which was shot in 1969, it's a yearning film, where there is constant yearning for someone or something that could have created relationships; there are people who are standing in line, leaning on the tube that is located along the apartment block, this is a typical representation of our courtyard, they are just like what Marx said about French peasants, their relationship could described as two potatoes in a sack of potatoes, they aren't really waiting for something, it's more like that they are yearning something that will tie them together, something that's going to create a relationship between them. Their yearning can be clearly seen when they lose their patience and they start creating the subject, someone who could connect them together, and that subject turns out to be a stranger, a foreign worker from Greece: first of all because he is renting a room in their apartment complex, and because it is also to give a stranger any characteristics, you could create him with any individuality. "When he appeared I immediately knew that he was a communist» - says a bored young man, who was sitting on a bed after having boring sex. $-\langle$ From Greece?» - Doubt his words a woman, saying something along the lines of that in a country like Greece there is definitely no communists. - «I read it in a newspaper once, Greece is full of communists», - says the young man who could actually read. «Really?!» - «It's the truth.» (Pause) «Greece is full of communists.»The court: «Rosie learned that from François and told me». - «I can't believe that it's the truth». - «I agree. We should avoid him because he could cause us some problems, communists are a real threat to us.» - Bar: «He is a communist, and it is against the law here». - «It should be against the law, he came to our country and turns our he is one of them.» - «It is definitely illegal. We should do something» ${ }^{24}$. - Do something; here they are united by some action. If students who studied together are going to beat up the stranger from Greece, that means that that stranger, who is a communist in their opinion have awoken fascist feelings in them, he tied them together with his fascism methods. But that is definitely not necessary, maybe they will beat him up later because he didn't justify their beliefs, he didn't realize himself as a communist, they won't beat him up right away, they will wait until he will realize himself, and he will never do it. Just as Slavoy Zhizek noticed, fascism is a

\footnotetext{
${ }^{24}$ Катцельмахер (Katzelmacher, реж. Райнер Вернер Фассбиндер, 1969), 65-ая минута.
} 
reaction to a an unsuccessful revolution that has never happened, it's the revenge of the revolution because it was unsuccessful, it's the revenge of those who were lead into this road and were dropped half-way thought. They all expect something from the Greek, just like one of the girls, Gunda is the only one who does not have a lover, awaits that she is going to be raped by the Greek, isn't that common in Greece? They all await that that the Greek is going fertilize them, but he is just like all of them infertile. This misfortune happened because two nothings met. - When Maria, a woman who says that she tied herself in love with the Greek says that «this summer we are going on a trip to Greece». We could feel that this trip is never going to happen just like all of these young people have said. - Let's talk about Fassbinder, for example, Fassbinder is not really demanding, he doesn't demand the truth, he doesn't need us to reach the high peaks in the ending, that this tale would become reality someday, the only thing that he wants is to see this cycle of repetitions finally ending, repetitions that make our stupid and asleep, maybe that's because that movie ended with words that even the German youth, nor the Greek could justify these words: "Its better to make new mistakes than repeating our old ones again and again»

\section{SUMMARY}

Nowadays cinematography could help us to learn history, or at least learn what made people make important historical decisions, if we aren't assuming that history is just statistic data and «true facts», that means that we need to understand even the illusions of people who are taking action, one way or another in a historical way. Cinematography is a witness of historical events. In the twentieth years of past century a cinematograph by the name of Dziga Vetrov became a new-founder of a new genre of motion pictures, its name already tells us what is it about «The Motion Picture of Truth», «Motion picture-eyes» «A man with a camera», shortly, he did something absolutely new based on past experience of realityshows, it was without actors, without a scenario, and without decorations. Dziga Vetrov believed that he captures the making of history with his camera and that history is being made in every moment and every action, maybe even in actions of pioneers, that portrait the adult visitors of bar like friends of tuberculosis. The more quietness comes and the realization of that quietness cinematography with fixation of making history is 
changing its genre to experiencing the repetition of history that has been already made, and that experience, or if we were to say it in a philosophical language, reflection in history becomes some sort of saving «the connection of times». Maybe cinematography is producing illusions, but its attitude towards illusion changes in that exact period changes, people try to find an illusion hoping that it would re-connect human relationships and connections, that it will give people strength to reach historical time, to re-new the nowadays stale process of creating history. The main contribution to new cinematography and old cinematography was contributed by unknown producers; it was them who came back to the times of revolution in France, Spain and Greece. This is why I chose exactly these films and producers in this article: Jean Marie Straub and Danielle Yue, Theo Angelopoulos, Alain Resnais, Reiner Werner Fassbinder and the others.

\section{FILMOGRAPHY}

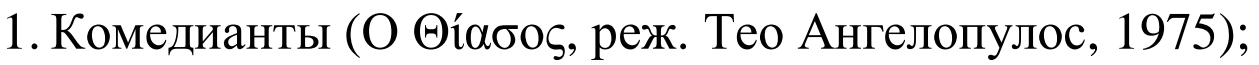

2. Ангел истребления (El ángel exterminador, реж. Луис Бунюэль, 1962);

3. Герника (Guernica, реж. Ален Рене, 1950);

4. Хиросима, любовь моя (Hiroshima mon amour, реж. Ален Рене, 1959);

5. Прошлым летом в Мариенбаде (L'Annee derniere a Marienbad, реж. Ален Рене, 1961);

6. Война окончена (La guerre est finie, реж. Ален Рене, 1966);

7. «Вперёд, сыны отечества!» (Allonsanfan, реж. братья Тавиани, 1974); 1969);

8. Катцельмахер (Katzelmacher, реж. Райнер Вернер Фассбиндер,

9. Слишком рано - слишком поздно (Trop tot - Trop tard, peж. Жан-Мари Штрауб и Даниэль Юйе, 1981).

\section{REFERENCES}

1. Гегель Г. В. Ф. Наука логики: в 3-х томах. М.: Мысль, 1970, т. 1, $501 \mathrm{c.}$

2. Делёз Ж. Кино. Кино 1: Образ-движение. Кино 2: Образвремя. М.: Ад Маргинем, 2004, 626 с. 
3. Энгельс Ф. Карлу Каутскому, 20 февраля 1889 г. // Сочинения, 2-е изд. М.: Политиздат, 1965, т. 37, с. 125-130.

4. Эсхил. Агамемнон // Трагедии. М.: Искусство, 1978, с. 181-246.

Information about the author:

Predeina M. Yu.

Candidate of Philosophical Sciences, Senior Lecture at the Department of Philosophy and History,

V. I. Vernadsky Taurida National University, 33, Ivana Kudri str., Kyiv, Ukraine.

E-mail: m.y.predeina@gmail.com 